\title{
Epidemiology of Cervical Spine Injuries in The Emergency Department at The University Hospital of The West Indies, Jamaica and The Use of Clinical Decision Rules, A Retrospective Review.
}

\section{Olsheath Bowen (First Author)}

The University of the West Indies at Mona Faculty of Medical Sciences

C Walters

University of the West Indies

\section{Eric Wilson Williams}

The University of the West Indies at Mona Faculty of Medical Sciences

\section{Leohrandra Graham}

The University of the West Indies at Mona Faculty of Medical Sciences

Jean Williams-Johnson (last author) ( $\sim$ jeanwilliamsjohnson@gmail.com )

University of the West Indies at Mona https://orcid.org/0000-0003-2967-6453

\section{Original Research}

Keywords: cervical spine injury, epidemiology, NEXUS Low-Risk criteria, CCR criteria

Posted Date: June 8th, 2021

DOI: https://doi.org/10.21203/rs.3.rs-570562/v1

License: (c) (i) This work is licensed under a Creative Commons Attribution 4.0 International License. Read Full License 


\section{Abstract}

Background: Cervical spine injuries are myriad and ubiquitous, however the related demographic information has not been documented for the Jamaican or Caribbean population. These injuries can be life threatening and so it is important for the Emergency Physician to adhere to guidelines which direct management decisions including the need for imaging. This study therefore is an effort to report on the epidemiology of patients with cervical spine injuries presenting to the Emergency Department (ED) at the University Hospital of the West Indies (UHWI) and the use of clinical rules in the diagnosis of these injuries.

This was a retrospective study. The log books from the ED at the UHWI were used to identify patients presenting with possible cervical spine injuries from January 1, 2013 to December 31, 2016. Inclusion/exclusion criteria were applied to select study patients. Demographical and clinical information was collected and evaluated.

Results: 1,380 charts were identified as possible subjects. Of these, 887 charts were located and 806 (90.9\%) were eligible. Ages ranged from 16 to 101 years with an average of 37.5 years. The majority of subjects were male, with a male to female ratio of 3:1. The main causes of these injuries were motor-vehicle collision (46.4\%), motor-bike collision (23.8\%) and fall from elevation (13.1\%). Cervical spine injuries were identified in 20 (2.48\%) subjects where motor-vehicle collision (45\%) and motor-bike collisions (25\%) were the main cause for injuries. Documentation of clinical rules applied to determine the need for radiological testing were present for $37.7 \%$ of the study population (NEXUS $36.2 \%$, CCR $0.4 \%$ and combination $1.1 \%)$

Conclusion: The main source of injuries was due to road traffic accidents. This suggests more needs to be done regarding road safety. There is also room for improvement as it relates to the use of decision rules which may reduce the occurrence of unnecessary imaging.

\section{Background}

Trauma to the cervical spine can injure the bony elements causing fracture of the vertebra or damage to the neural elements. A spinal cord injury is defined as any traumatic disruption of the spinal cord, associated with extensive musculoskeletal involvement $[1,2]$. There are a wide variety of clinical presentations of cervical spine injury found in patients who present to the emergency room, making its diagnosis difficult [3]. Of patients presenting to the Emergency Department (ED) in the United Kingdom, approximately two percent will have a clinically important cervical spine injury caused by blunt trauma, for example motor vehicle collision or fall $[4,5]$. Spinal trauma is one of the most expensive burdens in the United States. For every fifteen to forty persons per million population, 12,000 of these, patient have paraplegia as a result of cervical spine injury. One thousands of these patients, will die during their time of admission, and 4,000 will die before admission [6].

At the University Hospital of the West Indies (UHWI), Jamaica the most commonly injured vertebra in the spine is C6[7]. Although no national figures are available for cervical spine injuries, an estimated US \$70 is the average cost of management of a trauma patient in the ED at the UHWI resulting in an annual cost of USD $\$ 578,000$ [7]. The development of clinical decision rules, the NEXUS Low-Risk Criteria and the Canadian C-spine Rule (CCR) which guide decisions to clinically clear the cervical spine have assisted Emergency Physicians around the world [3].The purpose of clinically clearing the cervical spine is to avoid missing injury to the spine, prevent permanent damage and extension of damage to the cervical spine and to avoid the many complications of immobilization [8]. With the application of the NEXUS Low-Risk Criteria and the CCR after a physical examination, the number of radiographic studies ordered should decrease.

The aim of this study is to report on the epidemiology of patients with cervical spine injuries and the use of clinical rules in the diagnosis of these injuries. This would determine the usefulness and adherence of the rules in the management of these patients and determine the need to ensure use of the guidelines

Page 2/10 


\section{Method}

This study was a retrospective descriptive study. Patients with a cervical spine injury and all patients with a history of head

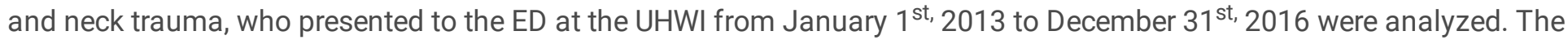
UHWI is a teaching hospital located in Kingston, Jamaica. Ethical approval was attained from the local ethics committee at the University of the West Indies Faculty of Medical Science. On average 53,000 patients are managed per year in the ED. Other studies surrounding trauma in the Accident and Emergency Department at the UHWI have been explored; however, this is the first documented study specific to cervical spine injury which has been conducted.

Charts of patients presenting to the ED at the UHWI with a history of head and neck trauma were suitable for the study inclusion. Patients' charts were retrospectively identified using the inclusion and exclusion criteria. Patients were included if they were over 16 years old, the injury occured within previous 48 hours and there was associated acute trauma to the head or neck. The risk of cervical spine injury with neck pain or no neck pain alongside one of the following: visible injury located above the clavicles, non-ambulatory, dangerous mechanism of injury were also inclusion criteria. Excluded patients were those with penetrating neck trauma, known to have a vertebral disease, previously evaluated for the same injury or where the injury occurred more than 48 hours prior to presentation.

The charts of all eligible patients were retrospectively reviewed. These patients' information was collected from existing medical records. The information recorded was stored in a secured filing cabinet while studied. As a retrospective study, there was to interference with patient care, and informed consent was not required.

The analysis of this data was done using the Statistical Package for Social Sciences (SPSS). Frequencies and percentages were calculated for categorical data. Parameters were analyzed within categories. The level of significance was predetermined at $p<0.05$. Using the Raosoft sample size calculator a sample of 800 patients would be needed to yield a clinically important study population.

\section{Results}

\section{Patient demographics}

A total of 188,714 persons presented to the ED during the period studied. Of these, 1,380 patients were identified as possible study subjects, with a total of 806 meeting the inclusion/exclusion criteria for analysis. The appropriate application of a screening tool was applied in 304 (37.8\%) patients.

\section{Gender and Age Distribution}

Figure 1 shows the age and gender distribution of the study population. The age range of the patients was 16 to 101 years, with a mean of 37.5 and a median of 42.5 years. The least number of patients were in the age range of 100 years and over (2 persons). Injuries occurred less frequently in females. More males were involved in trauma, with a male to female ratio of 3:1. Over the age of 79 years, injuries presented more often in females.

\section{Decision Instrument Used with The Participants Studied}

The comparisons of the use of the different rules applied in 806 patients studied are depicted in Fig. 2. There was no documentation of the rules being applied in 502 (62.3\%) of patients. When comparing the application of the NEXUS LowRisk Criteria and CCR, they were applied to 292 (36.2\%) and $3(0.4 \%)$ patients respectively. The NEXUS Low-Risk Criteria was the rule most frequently used for the assessment of patients. The combination of both NEXUS Low-Risk Criteria and CCR was used in nine patients (1.1\%). The CCR was applied in the minority of times.

\section{Mechanism of injury and outcome}


The mechanisms of injury most frequently documented were motor vehicle collision 374 (46.4\%), motorbike collision 192 (23.8\%) and fall from elevation 105 (13.1\%). Injury to the cervical spine, C-6 occurred in $12(1.5 \%)$ of these patients, and a total of 14 (1.7\%) developed neurological deficit. (Table 1).

Table 1

Characteristics of the 806 study participants presenting with a potential cervical spine injury

\begin{tabular}{|c|c|c|c|}
\hline Characteristics & n. (\%) & Characteristics & n. (\%) \\
\hline Mechanism of injury & & Cervical spine radiography performed & $518(64.3)$ \\
\hline Motor vehicle collision & $374(46.4)$ & Computed tomography performed & $140(17.4)$ \\
\hline Motorbike collision & $192(23.8)$ & & \\
\hline A collision involving other vehicles & $2(0.2)$ & Acute cervical Spine injury & $20(2.4)$ \\
\hline Pedestrian struck and thrown & $8(1)$ & Fracture & $17(2.1)$ \\
\hline Pedestrian struck & $28(3.5)$ & Dislocation & $2(0.2)$ \\
\hline Bicycle struck & $10(1.2)$ & Ligamentous instability & $1(0.1)$ \\
\hline Bicycle collision & $0(0)$ & Cervical spine injury to $\mathrm{C} / 6$ & $12(1.5)$ \\
\hline Other bicycle collision & $5(0.6)$ & Development of neurological deficit & $14(1.7)$ \\
\hline Fall from elevation $>10 \mathrm{ft}$. & $86(10.7)$ & & \\
\hline$(3 m)$ or down $>15$ stairs & & Stabilizing treatments & $20(2.4)$ \\
\hline Fall from elevation of 3-10ft. & $19(2.4)$ & Internal fixation & $4(0.5)$ \\
\hline$(1-3 m)$ or down 5 to 15 stairs & & Halo & $0(0)$ \\
\hline Assault with a blunt object & $3(0.4)$ & Brace & $0(0)$ \\
\hline Assault with fist or foot & $1(0.1)$ & Rigid collar & $16(1.9)$ \\
\hline Diving & $0(0)$ & & \\
\hline Fall onto head (axial loading) & $3(0.4)$ & Transferred from another institution & $77(9.6)$ \\
\hline Contact sports (axial loading) & $2(0.2)$ & Admitted to hospital - no (\%) & $335(41.6)$ \\
\hline Heavy object onto head & $0(0)$ & & \\
\hline \multicolumn{4}{|l|}{ (axial loading) } \\
\hline Other sports & $1(0.1)$ & & \\
\hline Head struck by another object & $12(1.5)$ & & \\
\hline Hit head on an object & $49(6.1)$ & & \\
\hline Other & $3(0.4)$ & & \\
\hline
\end{tabular}

\section{Demographics of patients with cervical spine injuries}

Twenty patients $(2.48 \%)$ in the study presented with a cervical spine injury Table 2 .. The age range was $19-56$ years, with a mean of 36.8 years. Males were the predominant gender with a male to female ratio of 6:1. The most common cervical spine fractured was C-6 (nine patients) followed by C-5 and C-7 with four each. The clinical decision rule used most often was the NEXUS Low-Risk Criteria (55\%). Due to lack of documentation, the method of cervical spine treatment in the eleven patients is unknown. 
Table 2

Patients with a cervical spine injury

\begin{tabular}{|c|c|c|c|c|c|c|c|c|c|}
\hline $\begin{array}{l}\text { Patient } \\
\text { No. }\end{array}$ & $\begin{array}{l}\text { Age } \\
\text { (yrs) }\end{array}$ & Sex & $\begin{array}{l}\text { Mechanism } \\
\text { of Injury }\end{array}$ & $\begin{array}{l}\text { Cervical } \\
\text { Spine Injury }\end{array}$ & $\begin{array}{l}\text { Other } \\
\text { Injuries }\end{array}$ & $\begin{array}{l}\text { Rule } \\
\text { Applied }\end{array}$ & $\begin{array}{l}\text { Other } \\
\text { Imaging }\end{array}$ & Admitted & $\begin{array}{l}\text { Cervical } \\
\text { Spine } \\
\text { Treatment }\end{array}$ \\
\hline 1 & 32 & $M$ & $\begin{array}{l}\text { MVC, } \\
\text { rollover }\end{array}$ & $\mathrm{C} 4$ fracture & None & NEXUS & No & Yes & $\begin{array}{l}\text { Internal } \\
\text { fixation }\end{array}$ \\
\hline 2 & 47 & M & $\begin{array}{l}\text { Fall 3-10 } \\
\mathrm{ft.}\end{array}$ & $\begin{array}{l}\text { C5-6 } \\
\text { subluxation }\end{array}$ & None & NEXUS & Yes & Yes & $\begin{array}{l}\text { Rigid } \\
\text { collar }\end{array}$ \\
\hline 3 & 19 & M & $\begin{array}{l}\text { Fall on } \\
\text { head }\end{array}$ & $\begin{array}{l}\text { C5-6 } \\
\text { displacement }\end{array}$ & None & NEXUS & Yes & Yes & $\begin{array}{l}\text { Internal } \\
\text { fixation }\end{array}$ \\
\hline 4 & 44 & M & $\begin{array}{l}\text { Pedestrian } \\
\text { struck }\end{array}$ & $\begin{array}{l}\text { C1 right } \\
\text { posterior } \\
\text { arch fracture }\end{array}$ & None & NEXUS & Yes & Yes & None \\
\hline 5 & 27 & M & MVC & C5-6 fracture & None & NEXUS & Yes & Yes & $\begin{array}{l}\text { Internal } \\
\text { fixation }\end{array}$ \\
\hline 6 & 22 & M & $\mathrm{MBC}$ & $\begin{array}{l}\text { C5 teardrop } \\
\text { fracture }\end{array}$ & $\begin{array}{l}\text { Mild head } \\
\text { injury }\end{array}$ & None & No & Yes & None \\
\hline 7 & 19 & $\mathrm{~F}$ & MVC & $\begin{array}{l}\text { C5 spinous } \\
\text { process } \\
\text { fracture }\end{array}$ & None & NEXUS & Yes & Yes & None \\
\hline 8 & 41 & $\mathrm{~F}$ & MVC & $\begin{array}{l}\text { C7-8 sensory } \\
\text { level }\end{array}$ & None & None & Yes & Yes & None \\
\hline 9 & 36 & M & MVC & C2-3 fracture & None & None & Yes & No & None \\
\hline 10 & 56 & $\mathrm{~F}$ & MVC & $\begin{array}{l}\text { C5-6 facet \& } \\
\text { lamina } \\
\text { fracture }\end{array}$ & $\begin{array}{l}\text { Frontal bone } \\
\text { fracture \& } \\
\text { subgleal } \\
\text { hematoma }\end{array}$ & None & Yes & Yes & None \\
\hline 11 & 24 & $M$ & $\mathrm{MBC}$ & $\begin{array}{l}\text { C7 open left } \\
\text { transverse } \\
\text { process } \\
\text { fracture }\end{array}$ & $\begin{array}{l}\text { Fracture of } \\
\text { the 5th } \\
\text { proximal } \\
\text { phalanx }\end{array}$ & NEXUS & No & Yes & None \\
\hline 12 & 44 & $M$ & Fall > $10 \mathrm{ft}$. & $\begin{array}{l}\text { C3 } \\
\text { transverse } \\
\text { process } \\
\text { fracture, C6 } \\
\text { spinous } \\
\text { process } \\
\text { fracture, C7 } \\
\text { transverse } \\
\text { process } \\
\text { fracture }\end{array}$ & None & NEXUS & Yes & Yes & None \\
\hline 13 & 42 & $M$ & $\mathrm{MBC}$ & $\begin{array}{l}\text { C spine } \\
\text { fracture }\end{array}$ & $\begin{array}{l}\text { Left femur } \\
\text { fracture }\end{array}$ & None & Yes & Yes & $\begin{array}{l}\text { Internal } \\
\text { fixation }\end{array}$ \\
\hline 14 & 62 & $\mathrm{M}$ & MVC & $\begin{array}{l}\text { C4-5 \& C5-6 } \\
\text { compression } \\
\text { fractures }\end{array}$ & $\begin{array}{l}\text { Left forearm } \\
\text { fracture \& } \\
\text { left fibula } \\
\text { fracture }\end{array}$ & None & Yes & Yes & None \\
\hline 15 & 40 & $M$ & $\mathrm{MBC}$ & $\begin{array}{l}\text { C5-6 facet } \\
\text { joint } \\
\text { comminuted } \\
\text { fracture }\end{array}$ & None & None & No & Yes & None \\
\hline
\end{tabular}




\begin{tabular}{|c|c|c|c|c|c|c|c|c|c|}
\hline $\begin{array}{l}\text { Patient } \\
\text { No. }\end{array}$ & $\begin{array}{l}\text { Age } \\
\text { (yrs) }\end{array}$ & Sex & $\begin{array}{l}\text { Mechanism } \\
\text { of Injury }\end{array}$ & $\begin{array}{l}\text { Cervical } \\
\text { Spine Injury }\end{array}$ & $\begin{array}{l}\text { Other } \\
\text { Injuries }\end{array}$ & $\begin{array}{l}\text { Rule } \\
\text { Applied }\end{array}$ & $\begin{array}{l}\text { Other } \\
\text { Imaging }\end{array}$ & Admitted & $\begin{array}{l}\text { Cervical } \\
\text { Spine } \\
\text { Treatment }\end{array}$ \\
\hline 16 & 26 & $M$ & $\mathrm{MBC}$ & $\begin{array}{l}\mathrm{C} 2, \mathrm{C} 3, \mathrm{C} 7 \\
\text { fracture }\end{array}$ & None & None & Yes & Yes & None \\
\hline 17 & 51 & M & MVC & C6 fracture & $\begin{array}{l}\text { Multiple } \\
\text { vertebral } \\
\text { fractures \& } \\
\text { right } \\
\text { femoral } \\
\text { fracture }\end{array}$ & NEXUS & Yes & Yes & $\begin{array}{l}\text { Rigid } \\
\text { collar }\end{array}$ \\
\hline 18 & 29 & M & $\begin{array}{l}\text { Fall on } \\
\text { head }\end{array}$ & C7 fracture & None & NEXUS & Yes & Yes & $\begin{array}{l}\text { Rigid } \\
\text { collar }\end{array}$ \\
\hline 19 & 41 & M & MVC & C6 fracture & None & NEXUS & No & Yes & $\begin{array}{l}\text { Rigid } \\
\text { collar }\end{array}$ \\
\hline 20 & 35 & $M$ & Fall > $10 \mathrm{ft}$. & C5 fracture & Quadriplegia & None & No & Yes & None \\
\hline
\end{tabular}

\section{Discussion}

Road traffic accidents are the second most common cause of admission for trauma to the University Hospital of the West Indies (9). The 2017 annual traffic crash report of Jamaica found 321 persons were killed as a result of 292 motor vehicle crashes (10). Victims of motorcycle collision and motorbike collision sustain serious injuries (9). A study done by Ward et al. examined the cost of violence-related injuries in Jamaica (11). The total cost of violence related injuries in 2014 was JMD $\$ 3.6$ billion which represents $22 \%$ of the health budget of Jamaica. Trauma plays an important role in the financial burden of the health system (11).

This study showed that the majority of patients (46.4\%) presenting with potential cervical spine injury was caused by motor vehicle collisions. The second most common presenting cause was motorbike collisions representing $23.8 \%$ of patients. In total $76.7 \%$ of the potential injuries were as a result of road traffic accidents. When males were compared to females, males presented more frequently with a ratio of 3:1. This study's findings is in keeping with other studies done within Jamaica and worldwide.

We found the NEXUS Low-Risk Criteria was used more often than the CCR in deciding the need for radiograph in the emergency department of the University Hospital of the West Indies.

In a study done by Elseton et al., and another done by Poonnoose et al., the overutilization of cervical spine imaging by emergency physicians despite the recommended use of the NEXUS Low-Risk criteria and CCR was found (12).

Overutilization was also shown in this study with the performance of 243 (55\%) cervical spine X-Rays in patients without the application of a clinical decision rule.

Of the 806 patients who were studied, $20(2.48 \%)$ of these had a cervical spine injury. The average age of a patient with injury was 36.8 years with a male to female ratio of $6: 1$. The NEXUS Low-Risk criteria were applied to 11 of these patients, and nine patients had pathologies which were diagnosed without the application of criteria. Motor collisions (motorbike collisions and motor car collisions) were the most common mechanism of injury 14 patients (70\%) were the most common mechanism of injury found.

In a study done by Dickinson et al. $(n=8,924)$, cervical spine injuries were found in $14(0.16 \%)$ patients; this percentage was significantly smaller than $2.48 \%$ found in this study. The average age of patient with injury was 56.57 years with a male to female ratio of (2:1), this study had an average age of 36.8 years representing a younger population. Fall from height was the most common mechanism to cause injury to the cervical spine; it represented $71.41 \%$ in comparison to this 
study which was represented by motor collision $70.0 \%$. The other two mechanisms of injury in the study by Dickinson et al. were motor vehicle collisions and trampled by horse $21.48 \%$ and $7.14 \%$ respectively (13).

The cervical spine injuries which resulted from motor collision occurred at C2-7. The injuries caused by motor collisions were, displacements, teardrop fracture, spinous process fracture, facet and laminar fracture, open transverse process fracture, compression fracture, and comminuted fracture. Other injuries associated with motor collision were a frontal bone fracture, subgleal hematoma, fracture of the 5th proximal phalanx, left femur fracture, left forearm fracture, left fibula fracture, multiple vertebral fractures, and right femoral fracture.

The two methods of cervical spine treatment used in this study were internal fixation and the application of a rigid collar. Internal fixation was applied in four $(20 \%)$ of patients, and treatment with a rigid collar was documented in only four (20\%) of the patients. The majority of these patients $60 \%$ had no treatment used documented. All patients presenting to the University Hospital of the West Indies with head or neck injuries will have stabilization of their cervical spine. This is mostly done with the application of a rigid (hard) cervical collar. Lack of documentation may account for most patients having had no treatment recorded for their cervical spine injury. When compared to the study done by Dickinson et al., their methods of treatment were a hard collar, halo, internal fixation and soft collar representing $57.14 \%, 21.43 \%, 14.29 \%$ and $7.14 \%$ respectively (13).

The most common types of injuries to the cervical spine were fractures and dislocations to the C3-7 region (3). Injuries to the cervical spine occur most commonly at two points. One half are found at C5-7 region and one third at C-2 (14). The most common cervical spine vertebrae fracture in this study were C5 and C-6 (45\%). A study on spinal injuries done by Bruce et al., at the University Hospital of the West Indies showed C- 6 to be the cervical vertebra most commonly fractured, (15). Other common injuries found in the study by Bruce et al., were to the lumbar spine and the thoracic region (15).

In this retrospective study, a limitation was that some of the dockets could not be found. Of 1,380 medical record numbers collected from the Emergency Department logbooks, only 887 dockets were recovered from the library.

\section{Conclusion}

In conclusion, cervical spine injuries were more common in this study population when compared to other studies. The main source of injuries was attributed to road traffic accidents which suggests more needs to be done regarding road safety. A clinical decision rule to determine the need for radiological tests were not carried out on the majority of patients resulting in possible overutilization of radiographs.

\section{Abbreviations}

CCR: Canadian C-Spine Rule; ED: Emergency Department; UHWI: University Hospital of the West Indies

\section{Declarations}

\section{Ethical approval}

This was received from the ethics committee of the University of the West Indies, Mona campus.

\section{Consent for publication}

Not applicable

\section{Informed consent}


This was a retrospective chart review and informed consent was not needed.

\section{Availability of data and materials}

The datasets used and/or analyzed during the current study are available from the corresponding author on reasonable request.

\section{Competing interests}

The authors declare that they have no competing interests

\section{Funding}

This research did not receive any specific grant from funding agencies in the public, commercial or not-for-profit sector

\section{Acknowledgements}

Not applicable

\section{Authors' Contributions}

Each author has made substantial contributions to the conception or design of the work; or the acquisition, analysis, orinterpretation of data; or the creation of new software used in the work; or have drafted the work or substantively revised it. OB conceptualized and designed the study and was instrumental in data collection. She also drafted the work and substantially revised it. LG analyzed and interpreted the patient data. CW selected the appropriate statistical program and analyzed and interpreted the patient data. All authors read and approved the final manuscript. OB LG, EWW and JWJ drafted the work and substantively revised it.

\section{References}

1. Kreinest M, Goller S, Rauch G, Frank C, Gliwitzky B, Wölfl CG, et al. Application of cervical collars-an analysis of practical skills of professional emergency medical care providers. PloS one. 2015;10(11):e0143409.

2. Mosby Elsevier. Mosby's Medical Dictionary: Elsevier Health Sciences; 2006.

3. Kanwar R, Delasobera BE, Hudson K, Frohna W. Emergency department evaluation and treatment of cervical spine injuries. Emergency Medicine Clinics. 2015;33(2):241-82.

4. Hasler RM, Exadaktylos AK, Bouamra O, Benneker LM, Clancy M, Sieber R, et al. Epidemiology and predictors of cervical spine injury in adult major trauma patients: a multicenter cohort study. Journal of trauma and acute care surgery. 2012;72(4):975-81.

5. Milby $\mathrm{AH}$, Halpern $\mathrm{CH}$, Guo W, Stein SC. Prevalence of cervical spinal injury in trauma. Neurosurgical focus. 2008;25(5):E10.

6. Guarnieri G, Izzo R, Muto M. The role of emergency radiology in spinal trauma. The British journal of radiology. 2016;89(1061):20150833.

7. Bruce CAD, G. ; Palmer, W.; Crandon, Ivor W. Spinal injuries at the University Hospital of the West Indies. West Indian Medical Journa. 2000;49(3):216-19.

8. Anderson PA, Muchow RD, Munoz A, Tontz WL, Resnick DK. Clearance of the asymptomatic cervical spine: a metaanalysis. Journal of orthopaedic trauma. 2010;24(2):100-6.

9. Crandon IW, Harding HE, Cawich S, McDonald A, Fearron-Boothe D. Motorcycle accident injury profiles in Jamaica: an audit from the University Hospital of the West Indies. International journal of injury control and safety promotion. 2009;16(3):175-8. 
10. Hare K. Annual Traffic Crash Report: December 31, 2017. Ministry of Transport and Mining Policy, Planning and Research Road Safety Unit; 2017.

11. E. Ward JT, T McCartney, P Lyew-Ayee, K McGaw, D Ashley. Viilence, health and development: examining the cost of violence-related injuries to Jamaica. West Indian Medical Journal. 2018;67((Suppl. 4)):23.

12. Griffith B, Bolton C, Goyal N, Brown ML, Jain R. Screening cervical spine CT in a level I trauma center: overutilization? American Journal of Roentgenology. 2011;197(2):463-7.

13. Dickinson G, Stiell IG, Schull M, Brison R, Clement CM, Vandemheen KL, et al. Retrospective application of the NEXUS low-risk criteria for cervical spine radiography in Canadian emergency departments. Annals of emergency medicine. 2004;43(4):507-14.

14. Greenbaum J, Walters N, Levy PD. An evidenced-based approach to radiographic assessment of cervical spine injuries in the emergency department. The Journal of emergency medicine. 2009;36(1):64-71.

15. Bruce C, Donaldson G, Palmer W, Crandon IW. Spinal injuries at the University Hospital of the West Indies. The West Indian medical journal. 2000;49(3):216-9.

\section{Figures}

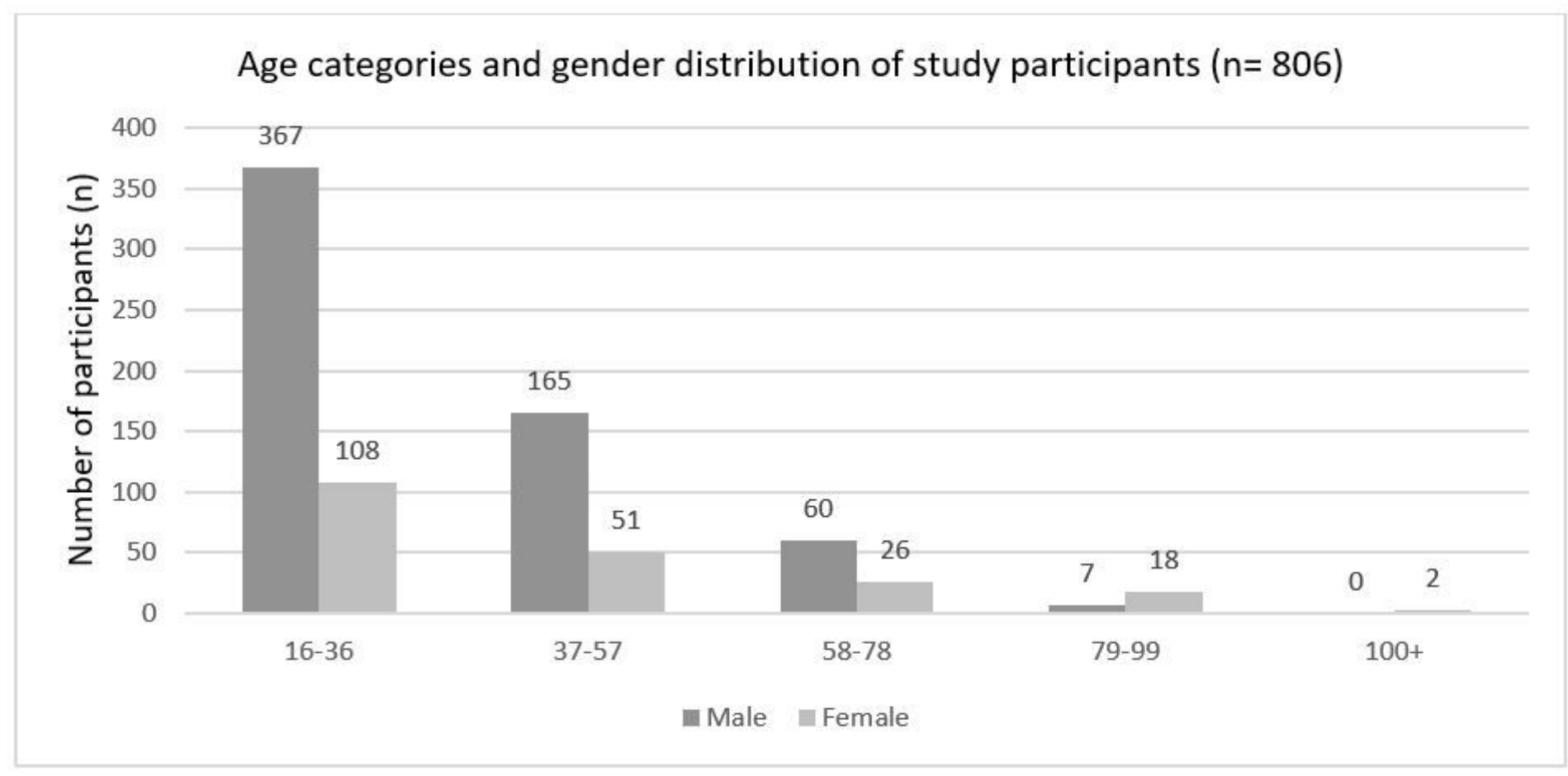

\section{Figure 1}

Age categories and gender distribution. 


\section{Use of decison instrument in participants studied with potential cervical spine injury $(n=806)$}

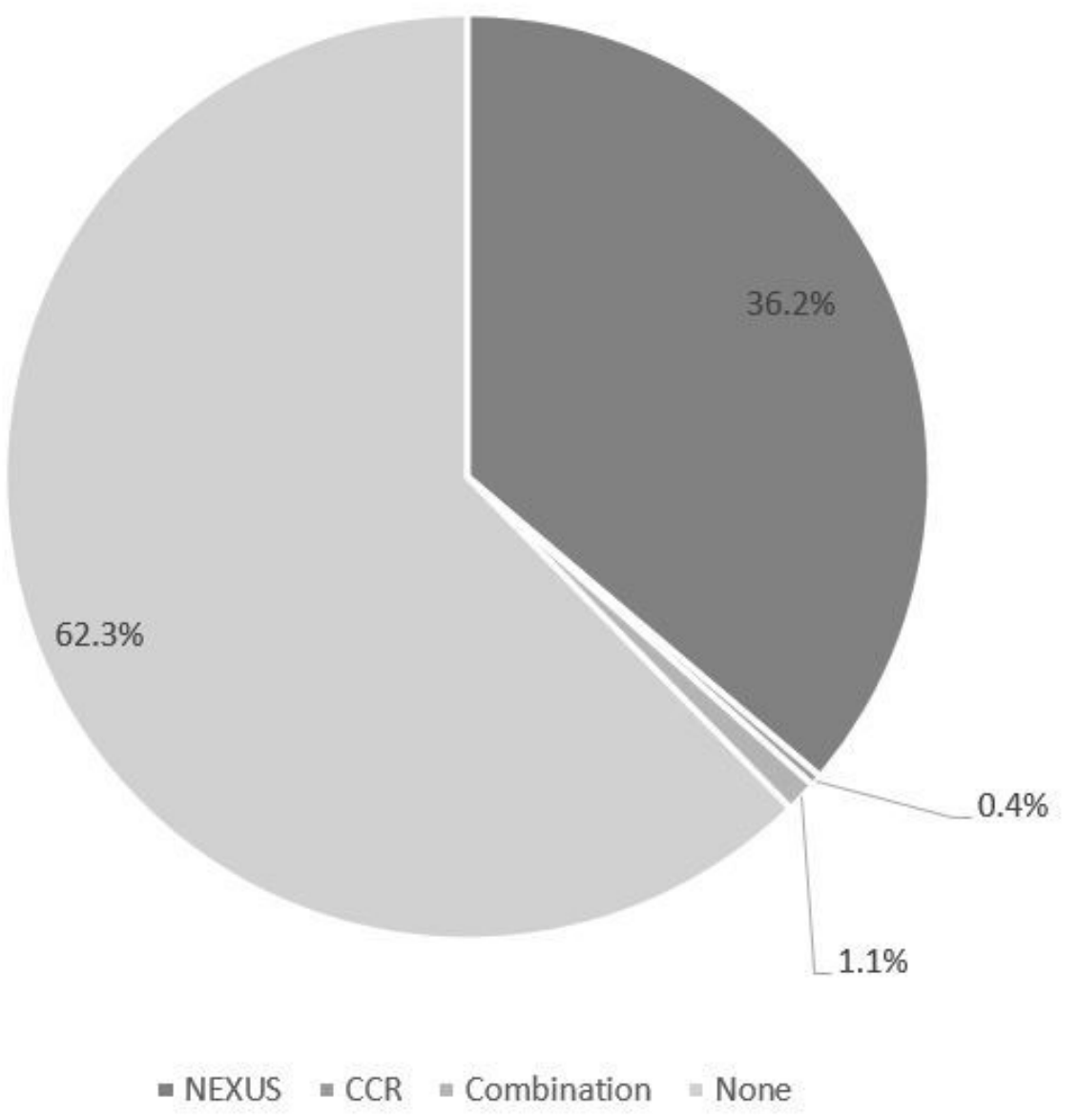

Figure 2

Criteria used in participants studied. 